\title{
Egyptiần Journal of Chemistry
}

http://ejchem.journals.ekb.eg/

\section{Green synthesis: Antimicrobial activity of novel benzothiazole-bearing coumarin derivatives and their fluorescence properties}

\author{
Nadia H. Metwally*1, Galal H. Elgemeie ${ }^{2}$ and Fatma G. Fahmy ${ }^{1}$ \\ ${ }^{1}$ Chemistry Department, Faculty of Science, Cairo University, Giza 12613, Egypt \\ ${ }^{2}$ Chemistry Department, Faculty of Science, Helwan University, Cairo 11785, Egypt
}

\begin{abstract}
A new benzothiazole derivatives 4a-f were prepared by the reaction of 2-cyanomethylbenzothiazole 1 with 2-hydroxy-5(aryldiazenyl)benzaldehyde derivatives 2a-f under thermal method in ethanol containing few drops of triethylamine. The previous reaction was reinvestigated at room temperature using grindstone technique using sodium hydroxide. The compounds 4a-f were transformed into benzothiazole-bearing coumarin derivatives 5a-f by refluxing in dioxane with few drops of conc. hydrochloric acid. The structure of the newly synthesized compounds $\mathbf{4 a - f}$ and $\mathbf{5 a - f}$ was established by spectral data. The compounds 5a-f showed fluorescence properties as well as antimicrobial activity.
\end{abstract}

Keywords: 2-cyanomethylbenzothiazole; grindstone method; coumarin derivatives; antimicrobial activity; fluorescence properties.

\section{Introduction}

Benzothiazole derivatives have a number of biological effects, including antibacterial [1], antimicrobial [2], anti-inflammatory [3], antiviral [4], and anticancer activity [5]. Ethoxzolamide (I), a commercial drug containing the benzothiazole moiety, is also used to treat glaucoma and duodenal ulcers, as well as a diuretic. Furthermore, Frentizole (II) is an immunosuppressive drug approved by the FDA, while Riluzole (III) is a medication used to treat amyotrophic lateral sclerosis. Also, Zopolrestat (IV) is a novel carboxylic acid aldose reductase inhibitor as shown in Figure 1.

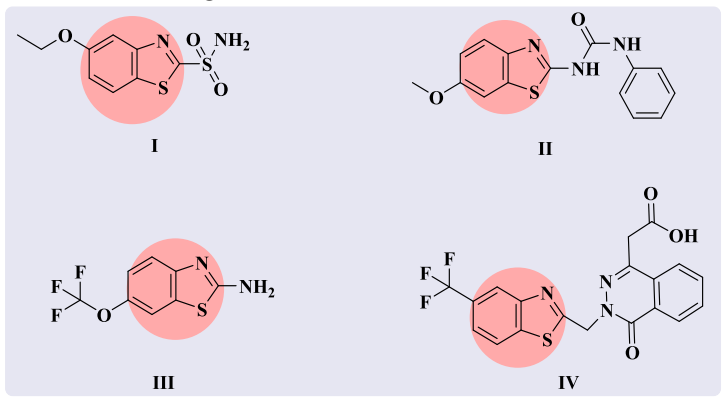

Fig.1. Some commercial drugs containing benzothiazole moiety

Coumarins, (known as benzopyran-2-ones) can be found within various natural sources for instance, fruits, essence, green tea, and other foods [6-8]. Coumarins are good class of naturally occurring compounds with promising therapeutic applications. Also, some substituted coumarins and polycyclic coumarins have gotten a lot of attention due to their broad range of biological activity like aminocoumarins (novobiocin and coumermycin) are antibiotics because they can inhibit DNA gyrase (Fig 2) [9]. Warfarin, a coumarin analogue, is an anticoagulant and a vitamin $\mathrm{K}$ antagonist $[10,11]$ and coumaphos is used as insecticide which kills insect and mites as shown in Figure 2 [12].

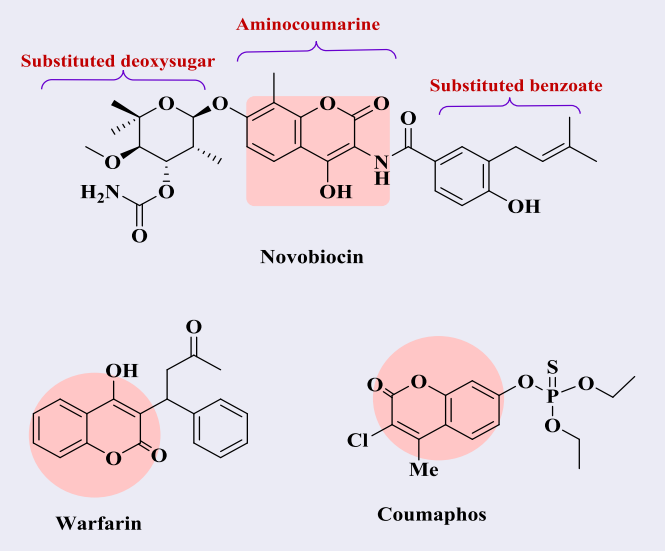

Fig. 2. Biological activity of coumarin analogs

*Corresponding author e-mail: nhmmohamed@ yahoo.com.; (Nadia Hanafy Metwally).

Receive Date: 22 August 2021, Revise Date: 18 October 2021, Accept Date: 25 August 2021

DOI: 10.21608/EJCHEM.2021.91887.4365

(C2022 National Information and Documentation Center (NIDOC) 
We recently published diverse synthetic approaches for the preparation of benzothiazole and coumarine derivatives using nitriles as starting materials [13,14].In light of these finding and as part of our program aimed at the preparation of possible antimetabolites [15-20], which showed biologically important antimetabolic agents in many biochemical reactions [21,22] and in accordance of these reports and based on our previous results in the preparation of biologically active heterocycles [23-28], the current study reports a new grindstone method synthesis of some novel benzothiazoles bearing a coumarin moiety 5a-f and investigate their antimicrobial activity as well as fluorescence properties.

\section{Material and methods}

\subsection{Measurements}

All melting points were determined using Electrothermal (9100) apparatus. At Ain Shams, the ${ }^{1} \mathrm{H}$ NMR spectra were recorded in DMSO- $d_{6}$ using $\mathrm{Si}(\mathrm{Me})_{4}$ as an internal norm on a Bruker Avance (III)400 Spectrometer $(400 \mathrm{MHz})$. At $70 \mathrm{eV}$, mass spectra were collected on a Shimadzu GCMS-QP 1000 Ex mass spectrometer. Elemental analyses were carried out at Cairo University's Microanalyses Center using a Vario EL III Elemental CHNS analyzer. At Cairo University, electronic absorption spectra were obtained using a UV-3101 pc spectrophotometer. A $700 \mathrm{~V}$ biassed face form photomultiplier was used at Cairo University to test fluorescent absorption. The laser device, monochromator, and photomultiplier tube, as well as the Spectra-Physics-Laser model 183C0201 and the Instrument Group amplifier model AD110, are all manufactured in the United States. The Biological Center at Cairo University conducted antimicrobial assessments. The preparation of compounds 1 and $\mathbf{2}$ was prepared according to the previous methods $[29,30]$.

\subsection{Synthesis procedures}

2.1. General procedures for the synthesis of compounds 4a-f

Method A

In $10 \mathrm{ml}$ absolute ethanol containing triethylamine, compound $1(0.01 \mathrm{~mol})$ and arylazosalicylaldehydes 2a-f $(0.01 \mathrm{~mol})$ were refluxed for 3 hours. The precipitated solid that formed by cooling was filtered off and recrystallized from ethanol / dioxane mixture.

\section{Method B}

Compound 1 (0.01 mol), arylazosalicylaldehydes $\mathbf{2 a -}$ f $(0.01 \mathrm{~mol})$, and solid sodium hydroxide $(0.01 \mathrm{~mol})$ were ground in a mortar for 30 minutes at room temperature, the reaction mixture was triturated with water, filtered off, and recrystallized to give the respective products 4a-f, which were identical to those obtained by method $\mathbf{A}$ in all aspects.

\subsubsection{3-(Benzo[d]thiazol-2-yl)-6-(phenyldi-} azenyl)-2H-chromen-2-imine (4a)

Pale orange, yield $62 \%$ (A), $70 \%$ (B); m.p. $222^{\circ} \mathrm{C}$; $v_{\max } / \mathrm{cm}^{-1}(\mathrm{KBr}) 3191(\mathrm{NH}), 1650(\mathrm{C}=\mathrm{N}), 1602$ $(\mathrm{N}=\mathrm{N}) ;{ }^{1} \mathrm{H}$ NMR $\left(\mathrm{DMSO}-d_{6}\right) \delta=7.49(\mathrm{~d}, 2 \mathrm{H}, J=7.6$ $\mathrm{Hz}, \mathrm{Ar}), 7.70-7.79(\mathrm{~m}, 5 \mathrm{H}, \mathrm{Ar}$ and $\mathrm{CH}), 7.95(\mathrm{~d}, 2 \mathrm{H}$, $J=9.2 \mathrm{~Hz}, \mathrm{Ar}), 8.08$ (d, 2H, $J=8.0 \mathrm{~Hz}, \mathrm{Ar}), 8.06(\mathrm{~d}$, $2 \mathrm{H}, J=8.4 \mathrm{~Hz}, \mathrm{Ar}), 9.45$ (s, 1H, NH); Anal. Calcd. for $\mathrm{C}_{22} \mathrm{H}_{14} \mathrm{~N}_{4} \mathrm{OS}$ : C, 69.09; H, 3.69; N, 14.65; S, 8.38. Found: C, 69.27; H, 3.51; N, 14.43; S, 8.56\%.

\subsubsection{3-(Benzo $[d]$ thiazol-2-yl)-6-( $p$-tolyldia-} zenyl)-2H-chromen-2-imine (4b)

Brown crystals, yield 66\% (A), 76\% (B); m.p. $204{ }^{\circ} \mathrm{C}$; $v_{\max } / \mathrm{cm}^{-1}(\mathrm{KBr}) 3221(\mathrm{NH}), 1648(\mathrm{C}=\mathrm{N}), 1603$ $(\mathrm{N}=\mathrm{N}) ;{ }^{1} \mathrm{H}$ NMR $\left(\mathrm{DMSO}-d_{6}\right) \delta=2.41\left(\mathrm{~s}, 3 \mathrm{H}, \mathrm{CH}_{3}\right)$, $7.40(\mathrm{~d}, 2 \mathrm{H}, J=8.4 \mathrm{~Hz}, \mathrm{Ar}), 7.66-7.78(\mathrm{~m}, 4 \mathrm{H}, \mathrm{Ar}$ and $\mathrm{CH}), 7.97$ (d, 2H, J = 7.2 Hz, Ar), 8.02-8.06 (m, 2H, Ar), 8.11-8.22 (m, 2H, Ar), 9.42 (s, 1H, NH); Anal. Calcd. for $\mathrm{C}_{23} \mathrm{H}_{16} \mathrm{~N}_{4} \mathrm{OS}$ : C, 69.68; H, 4.07; N, 14.13; S, 8.09. Found: C, 69.50; H, 4.26; N, 14.34; S, 8.28\%.

\subsubsection{3-(Benzo $[d]$ thiazol-2-yl)-6-((4-methoxy-} phenyl)diazenyl)-2H-chromen-2-imine (4c)

Brown crystals, yield $60 \%$ (A), $71 \%$ (B); m.p. $210^{\circ} \mathrm{C}$; $v_{\max } / \mathrm{cm}^{-1}(\mathrm{KBr}) 3227(\mathrm{NH}), 1654(\mathrm{C}=\mathrm{N}), 1606$ $(\mathrm{N}=\mathrm{N}) ;{ }^{1} \mathrm{H}$ NMR (DMSO- $\left.d_{6}\right) \delta=3.83\left(\mathrm{~s}, 3 \mathrm{H}, \mathrm{OCH}_{3}\right)$, 6.50 (d, 2H, $J=8.4 \mathrm{~Hz}, \mathrm{Ar}), 7.39-7.58$ (m, 3H, Ar), 7.90 (s, 1H, CH), 7.95 (d, 2H, $J=8.4$, Ar), 8.0-8.04 (m, 2H, Ar), 8.72-8.88 (m, 2H , Ar), 9.45 (s, 1H, NH); Anal. Calcd. for $\mathrm{C}_{23} \mathrm{H}_{16} \mathrm{~N}_{4} \mathrm{O}_{2} \mathrm{~S}: \mathrm{C}, 66.98 ; \mathrm{H}, 3.91$; , 13.58; S, 7.77. Found: C, 66.79; H, 3.73; N, 13.35; S, $7.59 \%$.

2.2.1.4. 3-(Benzo[d]thiazol-2-yl)-6-[(4-chlorophenyl)diazenyl]-2H-chromen-2-imine (4d)

Yellowish brown crystals, yield $71 \%$ (A), 80\% (B), m.p. $242{ }^{\circ} \mathrm{C}, v_{\max } / \mathrm{cm}^{-1}(\mathrm{KBr}) 3211(\mathrm{NH}), 1649$ $(\mathrm{C}=\mathrm{N}), 1603(\mathrm{~N}=\mathrm{N}) ;{ }^{1} \mathrm{H}$ NMR (DMSO- $\left.d_{6}\right) \delta=7.39$ (d, $2 \mathrm{H}, J=7.6 \mathrm{~Hz}, \mathrm{Ar}$ ), 7.39-7.58 (m, 3H, Ar), 7.90 (s, $1 \mathrm{H}, \mathrm{CH}), 7.95$ (d, 2H, J = 8.4, Ar), $8.0-8.04$ (m, $2 \mathrm{H}, \mathrm{Ar}), 8.72-8.88$ (m, 2H, Ar), 9.45 (s, 1H, NH); m/z $=416\left(\mathrm{M}^{+}, 33.2 \%\right), 417\left(\mathrm{M}^{+}+1,10.4\right), 399(13.9 \%)$, $290(12.6 \%), 277$ (25.9\%), 248 (25.0\%), $222(10.8 \%)$, 139 (12.9\%), 111 (100\%), 75 (48.7\%), 69 (18.6\%); Anal. Calcd. for $\mathrm{C}_{22} \mathrm{H}_{13} \mathrm{ClN}_{4} \mathrm{OS}$ : C, 63.39; H, 3.14; Cl, 8.50; N, 13.44; S, 7.69. Found: C, 63.57; H, 3.31; N, $13.68 ; \mathrm{S}, 7.86 \%$.

2.2.1.5. 3-(Benzo[d]thiazol-2-yl)-6-((4-chloro-2methylphenyl)diazenyl)-2H-chromen-2-imine (4e) Reddish brown crystals, yield 64\% (A), 68\% (B), m.p. $216^{\circ} \mathrm{C}, v_{\max } / \mathrm{cm}^{-1}(\mathrm{KBr}) 3235(\mathrm{NH}), 1663(\mathrm{C}=\mathrm{N})$, $1600(\mathrm{~N}=\mathrm{N}) ;{ }^{1} \mathrm{H}$ NMR (DMSO- $\left.d_{6}\right) \delta=2.33(\mathrm{~s}, 3 \mathrm{H}$, $\mathrm{CH}_{3}$ ), 6.39-6.52 (m, 3H, Ar), 7.29 (d, $2 \mathrm{H}, J=6.8 \mathrm{~Hz}$, 
Ar), 7.52-7.58 (m, 3H, Ar), 7.96 (s, 1H, CH), 8.0-8.04 $(\mathrm{m}, 2 \mathrm{H}, \quad$ Ar $), 9.43(\mathrm{~s}, 1 \mathrm{H}, \mathrm{NH}) ; \mathrm{m} / \mathrm{z}=430$ $\left(\mathrm{M}^{+}, 58.7 \%\right), 431\left(\mathrm{M}^{+}+1,20 \%\right), 413(15.5 \%), 385$ (3.2\%), 290 (16.7\%), 277 (34.9\%), $248(33.4 \%), 222$ (14.1\%), 153 (11.4\%), 127 (32.0\%), 125 (100\%), 99 (18.6\%), 89 (52.9\%), 77 (8.9\%), 63 (25.2\%); Anal. Calcd. for $\mathrm{C}_{23} \mathrm{H}_{15} \mathrm{ClN}_{4} \mathrm{OS}$ : C, 64.11; H, 3.51; Cl, 8.23; N, 13.00; S, 7.44. Found: C, 64.29; H, 3.34; N, 13.23; $\mathrm{S}, 7.61 \%$.

2.2.1.6. 3-(Benzo[d]thiazol-2-yl)-6-((2,4-dichlorophenyl)diazenyl)-2H-chromen-2-imine (4f)

Brown crystals, yield 61\% (A), 73\% (B); m.p. 208 ${ }^{\circ} \mathrm{C} ; v_{\max } / \mathrm{cm}^{-1}(\mathrm{KBr}) 3235(\mathrm{NH}), 1663(\mathrm{C}=\mathrm{N}), 1600$ $(\mathrm{N}=\mathrm{N}) ;{ }^{1} \mathrm{H}$ NMR (DMSO- $\left.d_{6}\right) \delta=7.51-6.52(\mathrm{~m}, 3 \mathrm{H}$, Ar), 7.29 (d, 2H, $J=6.8 \mathrm{~Hz}, \mathrm{Ar}), 7.52-7.58(\mathrm{~m}, 3 \mathrm{H}$, Ar), $7.96(\mathrm{~s}, 1 \mathrm{H}, \mathrm{CH}), 8.0-8.04(\mathrm{~m}, 2 \mathrm{H}, \mathrm{Ar}), 9.47$ (s, $1 \mathrm{H}, \mathrm{NH}$ ); Anal. Calcd. for $\mathrm{C}_{22} \mathrm{H}_{12} \mathrm{Cl}_{2} \mathrm{~N}_{4} \mathrm{OS}$ : C, 58.55; H, 2.68; Cl, 15.71; N, 12.41; S, 7.10. Found: C, 58.76; $\mathrm{H}, 2.87 ; \mathrm{N}, 12.65 ; \mathrm{S}, 7.29 \%$.

\subsubsection{Synthesis of compounds 5a-f.}

Compounds 4a-f are dissolved in dioxane with the addition of few drops of hydrochloric acid. The mixture was refluxed for 30 minutes, and the solid thus precipitated as a result of cooling was filtered out and recrystallized from a mixture of ethanol and dioxane.

2.2.2.1. 3-(Benzo[ $[d]$ thiazol-2-yl)-6(phenyldiazenyl)-2H-chromen-2-one (5a)

Orange crystals, yield $65 \%$, m.p. $254{ }^{\circ} \mathrm{C}, v_{\max } / \mathrm{cm}^{-1}$ $(\mathrm{KBr}) 1731(\mathrm{CO}), 1599(\mathrm{~N}=\mathrm{N}) ;{ }^{1} \mathrm{H}$ NMR (DMSO-d $)$ $\delta=7.49(\mathrm{~d}, 2 \mathrm{H}, J=7.6 \mathrm{~Hz}, \mathrm{Ar}), 7.70-7.79(\mathrm{~m}, 5 \mathrm{H}, \mathrm{Ar}$ and $\mathrm{CH}), 7.95(\mathrm{~d}, 2 \mathrm{H}, J=9.2 \mathrm{~Hz}, \mathrm{Ar}), 8.06(\mathrm{~d}, 2 \mathrm{H}, J$ $=8.4 \mathrm{~Hz}, \mathrm{Ar}), 8.08(\mathrm{~d}, 2 \mathrm{H}, J=8.0 \mathrm{~Hz}, \mathrm{Ar}) ; \mathrm{m} / \mathrm{z}=383$ $\left(\mathrm{M}^{+}, 20.0 \%\right), 278(40.7 \%), 250(5.6 \%), 222(13.0 \%)$, 196 (5.0\%), 105 (14.3\%), 77 (100\%), 69 (8.6\%), 51 (26.7\%); Anal. Calcd. for $\mathrm{C}_{22} \mathrm{H}_{13} \mathrm{~N}_{3} \mathrm{O}_{2} \mathrm{~S}: \mathrm{C}, 68.92 ; \mathrm{H}$, 3.42; N, 10.96; S, 8.36. Found: C, 68.73; H, 3.61; N, $10.74 ; \mathrm{S}, 8.54 \%$.

2.2.2.2. 3-(Benzo[d]thiazol-2-yl)-6-(p-tolyldiazenyl)-2H-chromen-2-one (5b)

Reddish brown crystals, yield $53 \%$, m.p. $246{ }^{\circ} \mathrm{C}, v_{\max } /$ $\mathrm{cm}^{-1}(\mathrm{KBr}) 1717$ (CO), $1607 \quad(\mathrm{~N}=\mathrm{N}) ;{ }^{1} \mathrm{H}$ NMR $\left(\mathrm{DMSO}-d_{6}\right) \delta=2.41\left(\mathrm{~s}, 3 \mathrm{H}, \mathrm{CH}_{3}\right), 7.40(\mathrm{~d}, 2 \mathrm{H}, J=8.4$ $\mathrm{Hz}, \mathrm{Ar})$, 7.66-7.78 (m, 3H, $\mathrm{Ar}$ and $\mathrm{CH}), 7.97$ (d, 2H, $J=7.2 \mathrm{~Hz}, \mathrm{Ar}), 8.02-8.06$ (m, 2H, Ar), 8.11-8.22 (m, $2 \mathrm{H}, \mathrm{Ar}) ; \mathrm{m} / \mathrm{z}=397\left(\mathrm{M}^{+}, 80.4 \%\right), 278(71.8 \%), 250$ (10.4\%), $222(24.9 \%), 196(8.0 \%), 178(5.5 \%), 119$ (22.1\%), 91 (100\%), 65 (32.5\%); Anal. Calcd. for $\mathrm{C}_{23} \mathrm{H}_{15} \mathrm{~N}_{3} \mathrm{O}_{2} \mathrm{~S}$ : C, 69.51; H, 3.80; N, 10.57; S, 8.07. Found: C, 69.32; H, 3.63; N, 10.79; S, 8.26\%.

2.2.2.3. 3-(Benzo[d]thiazol-2-yl)-6-((4-methoxyphenyl)diazenyl)-2H-chromen-2-one (5c)

Reddish brown crystals, yield $69 \%$, m.p. $258^{\circ} \mathrm{C}, v_{\max } /$ $\mathrm{cm}^{-1}(\mathrm{KBr}) 1718(\mathrm{CO}), 1605(\mathrm{~N}=\mathrm{N}) ;{ }^{1} \mathrm{H}$ NMR $\left(\mathrm{DMSO}-d_{6}\right) \delta=3.79\left(\mathrm{~s}, 3 \mathrm{H}, \mathrm{OCH}_{3}\right), 7.39(\mathrm{~d}, 2 \mathrm{H}, J=$ 7.6 Hz, Ar), 7.40-7.58 (m, 3H, Ar), $7.90(\mathrm{~s}, 1 \mathrm{H}, \mathrm{CH})$, 7.95 (d, 2H, $J=8.4$, Ar), 8.0-8.04 (m, 2H, Ar), 8.72$8.88(\mathrm{~m}, 2 \mathrm{H}, \mathrm{Ar}), \mathrm{m} / \mathrm{z}=413\left(\mathrm{M}^{+}, 24.3 \%\right), 278$
(15.6\%), 250 (3.6\%), 222 (9.3\%), 135 (28.5\%), 107 (100\%), 92 (32.9\%), 77 (48.5\%), 64 (16.1\%); Anal. Calcd. for $\mathrm{C}_{23} \mathrm{H}_{15} \mathrm{~N}_{3} \mathrm{O}_{3} \mathrm{~S}: \mathrm{C}, 66.82 ; \mathrm{H}, 3.66 ; \mathrm{N}, 10.16$; S, 7.75. Found: C, 66.99; H, 3.84; N, 10.39; S, 7.92\%. 2.2.2.4. (3-(Benzo[d]thiazol-2-yl)-6-(4-chlorophenyl)diazenyl)-2H-chromen-2-one (5d)

Reddish brown crystals, yield $65 \%$, m.p. $282^{\circ} \mathrm{C}, v_{\max } /$ $\mathrm{cm}^{-1}(\mathrm{KBr}) 1725(\mathrm{CO}), 1603(\mathrm{~N}=\mathrm{N}) ;{ }^{1} \mathrm{H}$ NMR $\left(\mathrm{DMSO}-d_{6}\right) \delta=7.39-7.60(\mathrm{~m}, 5 \mathrm{H}, \mathrm{Ar}), 7.90(\mathrm{~s}, 1 \mathrm{H}$, $\mathrm{CH}), 7.98$ (d, 2H, $J=8.4, \mathrm{Ar}), 8.05-8.09$ (m, 2H, Ar), 8.72-8.91 (m, 2H, Ar); m/z = $417\left(\mathrm{M}^{+}, 34.3 \%\right), 418$ $\left(\mathrm{M}^{+}+1,11.4 \%\right), 278(74.5 \%), 250(10.4 \%), 222$ (22.7\%), 196 (9.1\%), 139 (20.1\%), 111 (100\%), 75 (38.5\%), 69 (15.7\%); Anal. Calcd. for $\mathrm{C}_{22} \mathrm{H}_{12} \mathrm{ClN}_{3} \mathrm{O}_{2} \mathrm{~S}$ : C, 63.24; H, 2.89; Cl, 8.48; N, 10.06; S, 7.67. Found: C, 63.43; H, 2.72; N, 10.30; S, 7.86\%. 2.2.2.5. 3-(Benzo[d]thiazol-2-yl)-6-((4-chloro-2methylphenyl)diazenyl)-2H-chromen-2-one (5e) Brown crystals, yield $59 \%$, m.p. $274^{\circ} \mathrm{C}, v_{\max } / \mathrm{cm}^{-1}$ (KBr) 1741 (CO), $1596(\mathrm{~N}=\mathrm{N}) ;{ }^{1} \mathrm{H}$ NMR (DMSO-d $)$ $\delta=2.36\left(\mathrm{~s}, 3 \mathrm{H}, \mathrm{CH}_{3}\right), 6.39-6.52(\mathrm{~m}, 3 \mathrm{H}, \mathrm{Ar}), 7.29$ (d, $2 \mathrm{H}, J=6.8 \mathrm{~Hz}, \mathrm{Ar}), 7.52-7.58(\mathrm{~m}, 3 \mathrm{H}, \mathrm{Ar}), 7.96(\mathrm{~s}$, $1 \mathrm{H}, \mathrm{CH}), 8.01-8.05(\mathrm{~m}, 2 \mathrm{H}, \mathrm{Ar}) ; \mathrm{m} / \mathrm{z}=431$ $\left(\mathrm{M}^{+}, 38.2 \%\right), 432\left(\mathrm{M}^{+}+1,13.1 \%\right), 403(3.1 \%), 278$ (55.0\%), 250 (10.1\%), 222 (26.4\%), 196 (9.4\%), 153 (12.9\%), 127 (30.9\%), 125 (100\%), 99 (15.2\%), 89 (43.3\%), 69 (11.9\%), 63 (21.7\%); Anal. Calcd. for $\mathrm{C}_{23} \mathrm{H}_{14} \mathrm{ClN}_{3} \mathrm{O}_{2} \mathrm{~S}: \mathrm{C}, 63.96 ; \mathrm{H}, 3.27 ; \mathrm{Cl}, 8.21 ; \mathrm{N}, 9.73$; S, 7.42. Found: C, 63.78; H, 3.46; N, 9.95; S, 7.63\%. 2.2.2.6. 3-(Benzo[d]thiazol-2-yl)-6-((2,4-dichlorophenyl)diazenyl)-2H-chromen-2-one (5f)

Reddish brown crystals, yield $63 \%$, m.p. $262{ }^{\circ} \mathrm{C}, v_{\max } /$ $\mathrm{cm}^{-1}(\mathrm{KBr}) 1717(\mathrm{CO}), 1605(\mathrm{~N}=\mathrm{N}) ;{ }^{1} \mathrm{H}$ NMR $\left(\mathrm{DMSO}-d_{6}\right) \delta=6.52-7.11(\mathrm{~m}, 3 \mathrm{H}, \mathrm{Ar}), 7.32(\mathrm{~d}, 2 \mathrm{H}, J$ $=6.4 \mathrm{~Hz}, \mathrm{Ar}), 7.56-7.62(\mathrm{~m}, 3 \mathrm{H}, \mathrm{Ar}), 7.96(\mathrm{~s}, 1 \mathrm{H}$, $\mathrm{CH}), 8.02-8.07(\mathrm{~m}, 2 \mathrm{H}, \mathrm{Ar}) ; \mathrm{m} / \mathrm{z}=450\left(\mathrm{M}^{+}, 30.0 \%\right)$, $451\left(\mathrm{M}^{+}+1,9.2 \%\right), 452\left(\mathrm{M}^{+}+2,14.5 \%\right), 306(2.3 \%)$, $278(100 \%), 250(12.0 \%), 222(26.5 \%), 196(8.4 \%)$, $173(8.5 \%), 145$ (22.4\%), $109(10.5 \%), 69(6.0 \%)$; Anal. Calcd. for $\mathrm{C}_{22} \mathrm{H}_{11} \mathrm{Cl}_{2} \mathrm{~N}_{3} \mathrm{O}_{2} \mathrm{~S}$ : C, 58.42; H, 2.45; $\mathrm{Cl}, 15.68$; N, 9.29; S, 7.09. Found: C, 58.60; H, 2.66; $\mathrm{N}, 9.51 ; \mathrm{S}, 7.27 \%$.

\subsection{Biological evaluation}

\subsubsection{Antimicrobial assay}

Using the agar well diffusion process, the coumarin derivatives 5a-f were tested against bacteria such as staphylococcus aureus and Streptococcus mutans (Gram positive bacteria), Escherichia coli, Pseudomonas aeruginosa, and Klebsiella pneumonia (Gram negative bacteria) [31]. The compounds were measured against bacterial and fungal strains at a concentration of $15 \mathrm{mg} / \mathrm{ml}$, with DMSO as the control. 


\subsubsection{Method of testing}

The following steps were followed in order to assess antimicrobial activity:

i- Preparing the sterilized Petri dishes (20-25 ml, each petri dish) and add on it the sterilized media and take of at room temperature till solidified.

ii- Making a microbial suspension in sterilised saline proportionate to McFarland 0.5 standard solution (1.5x $105 \mathrm{CFU} \mathrm{ml}^{-1}$ ) and adjusting the turbidity to OD $=0.13$ using a spectrophotometer at $625 \mathrm{~nm}$.

iii- A sterile cotton swab was plunged into the modified suspension and overflowed on the dried agar surface within 15 minutes of changing the turbidity of the inoculum suspension. This was then allowed to dry for 15 minutes with the lid in place.

iv- Wells of $6 \mathrm{~mm}$ diameter was made within the solidified media with the assistance of sterile borer.

v- By micropipette $100 \mu$ l of tested compound solution was added to each well.

vi- In the antibacterial activity, the plates were incubated at $37{ }^{\circ} \mathrm{C}$ for $24 \mathrm{hrs}$.

vii- This experiment was performed in triplicate and zones of inhibition were measured in $\mathrm{mm}$ scale.

\section{Results and Discussion}

The isolated products $\mathbf{4 a - f}$ were obtained by the condensation of 2-cyanomethylbenzothiazole $\mathbf{1}$ with various arylazosalicylaldehdes $\mathbf{2 a - f}$ under reflux in ethanol in the presence of triethylamine (Scheme 1). The above reaction was reinvestigated using the grindstone process as a green method with a better yield and short time. So compound $\mathbf{1}$ was grand with arylazosalicylaldehdes $\mathbf{2 a - f}$ in a mortar for 30 minutes using solid sodium hydroxide. Based on melting points and mixed melting points of the obtained products as well as their spectral data and elemental analyses, both protocols (A or B) afforded the same products 4a-f (see Scheme 1, Table 1 and Figure 3). The structures of $\mathbf{4 a - f}$ were proved using spectroscopic techniques. For example the IR spectrum of $\mathbf{4 d}$ revealed absorption bands at $3211 \mathrm{~cm}^{-}$ ${ }^{1}(\mathrm{NH})$ and $1649 \mathrm{~cm}^{-1}(\mathrm{C}=\mathrm{N})$. The ${ }^{1} \mathrm{H}$ NMR spectrum of $\mathbf{4 d}$ showed two singlets at $\delta=7.90$ and $9.45 \mathrm{ppm}$ which were assigned to $\mathrm{NH}$ and $\mathrm{CH}$ protons, respectively, besides, the signals corresponding to aryl protons. The mass spectrum revealed molecular ion peaks at $\mathrm{m} / \mathrm{z}=416\left(\mathrm{M}^{+}\right)$and $417\left(\mathrm{M}^{+}+1\right)$, which corresponds to the molecular formula of the assigned structure.

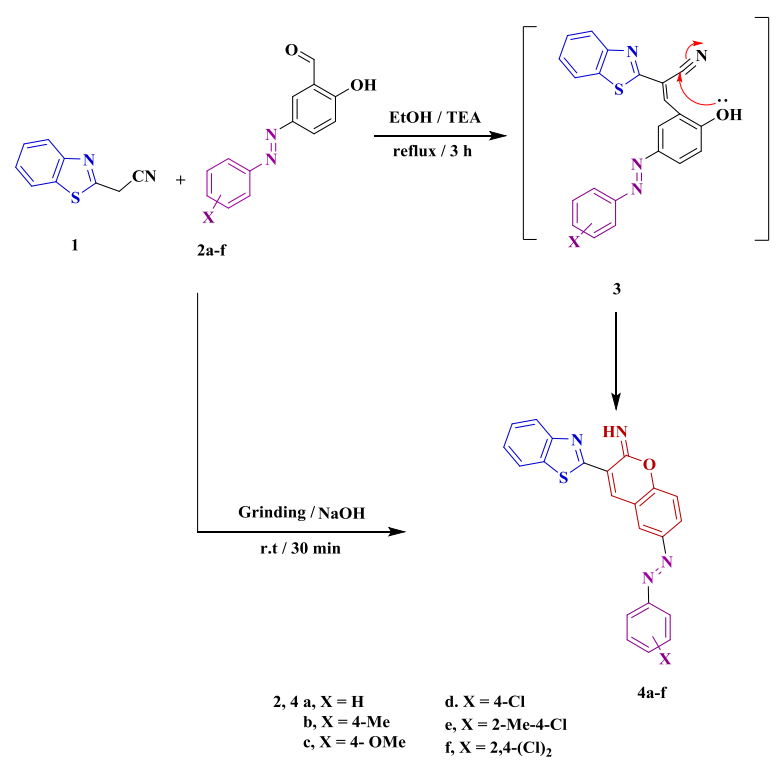

Scheme 1

Table 1. Comparison between the yield \% of $4 a-f$

by methods $A$ and $B$

\begin{tabular}{|c|c|c|}
\hline Compound no. & $\begin{array}{c}\text { EtOH / TEA/ } \\
\text { reflux } \\
\text { (Yield \%) }\end{array}$ & $\begin{array}{c}\text { NaOH / } \\
\text { Grinding } \\
\text { (Yield \% })\end{array}$ \\
\hline $4 a$ & 62 & 70 \\
\hline $4 \mathbf{b}$ & 66 & 71 \\
\hline $4 \mathbf{c}$ & 60 & 80 \\
\hline $4 \mathbf{4 e}$ & 71 & 68 \\
\hline $4 \mathbf{f}$ & 64 & 73 \\
\hline
\end{tabular}

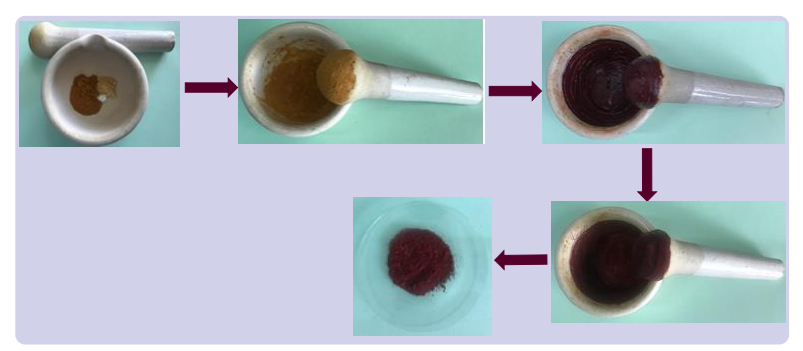

Fig. 3. Reaction sequence of formation of compound

4c

Compounds 4a-f were refluxed in dioxane in the presence of few drops of concentrated hydrochloric acid to afford the products $\mathbf{5 a - f}$ (Scheme 2 ). The structure of the products was proved by spectroscopic data. Thus, compound 5c appeared absorption band at $1718 \mathrm{~cm}^{-1}$ which corresponding to the $\mathrm{CO}$ group in its IR spectrum. Its ${ }^{1} \mathrm{H}$ NMR 
spectrum exhibited two singlet signals at $\delta=3.79$ and $7.90 \mathrm{ppm}$ due to the $\mathrm{OCH}_{3}$ and $\mathrm{CH}$ protons, respectively, in addition to signals corresponding to aryl protons. In addition, its mass spectrum revealed a molecular ion peak at $\mathrm{m} / \mathrm{z}=413\left(\mathrm{M}^{+}\right)$, confirmed the molecular formula $\mathrm{C}_{23} \mathrm{H}_{15} \mathrm{~N}_{3} \mathrm{O}_{3} \mathrm{~S}$.

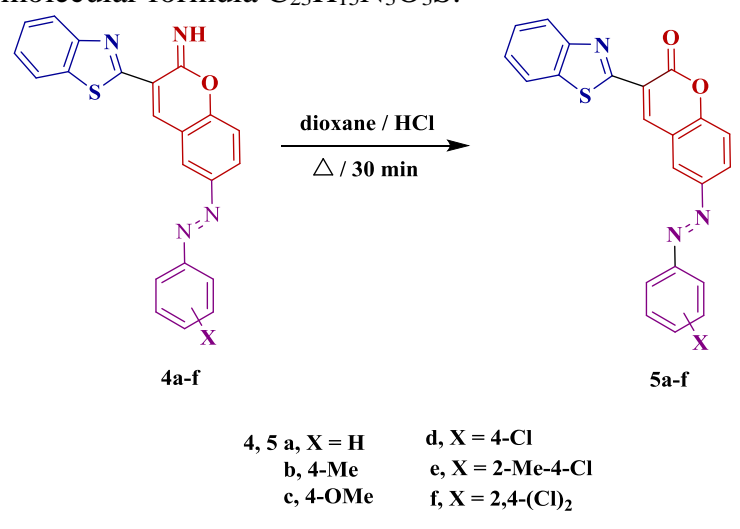

\section{Antimicrobial activity}

The prepared coumarins 5a-f were investigated toward Gram positive bacteria like Staphylococcus aureus (ATCC:13565), and Streptococcus mutans (ATCC:25175). Also, they investigated against Gram negative bacteria such as Escherichia coli (ATCC:10536), Klebsiella pneumonia (ATCC:10031) and Pseudomonas aeruginosa (ATCC:27853), additionally against fungi as example Candida albicans (ATCC:10231) and Asperagillus Nigar (ATCC:16404). The data summarized in Table 2, indicated that all the tested compounds have antibacterial effect toward Staphylococcus aureus (ATCC:13565) using ampicillin as standard drug and they exhibited antifungal activity toward Candida albicans (ATCC:10231) using Nystatin as reference drug.

Scheme 2

Table 2. Antimicrobial activity of compounds 5a-f

\begin{tabular}{|c|c|c|c|c|c|c|c|}
\hline Sample & $5 \mathbf{5 a}$ & $5 \mathbf{b}$ & $5 c$ & $5 d$ & $5 e$ & $5 f$ & Ref. \\
\hline Gram -ve & & & & & & & Gent. \\
\hline E. coli & E. coli & NA & $14.3 \pm 0.5$ & NA & $11.3 \pm 0.5$ & NA & NA \\
\hline K.pneum. & K.pneum. & NA & $12.3 \pm 0.5$ & NA & NA & NA & NA \\
\hline P. aerug. & P. aerug. & NA & $14.3 \pm 0.5$ & NA & NA & NA & NA \\
\hline Gram +ve & & & & & & & Amp. \\
\hline S. aureus & 14.6 & $25.3 \pm 0.5$ & $20.3 \pm 0.5$ & $10.6 \pm 0.5$ & $15.3 \pm 0.5$ & 20.3 & $22 \pm 0.1$ \\
\hline S. mutans & 14.3 & $12.6 \pm 0.6$ & $11.6 \pm 0.5$ & $\mathrm{NA}$ & $\mathrm{NA}$ & NA & $30 \pm 0.5$ \\
\hline Fungi & & & & & & & Nyst. \\
\hline C.alb. & 12.3 & $12.3 \pm 0.5$ & $12.3 \pm 0.5$ & $12.3 \pm 0.5$ & NA & 13.3 & $21 \pm 0.5$ \\
\hline A. Nigar & NA & NA & NA & NA & NA & NA & $19 \pm 0.5$ \\
\hline
\end{tabular}

Compound $\mathbf{5 b}$ showed moderate potency against the four types of bacteria than the other tested compounds. On the other hand, 5b showed strong activity $(25.3 \pm 0.6)$ towards Staphylococcus aureus than the reference drug ampicillin (22 \pm 0.1$)$. Also, $\mathbf{5 b}$ showed a moderate activity against the Candida albicans (ATCC:10231).

\section{UV and fluorescence Determination}

It have been reported that fluorescent natural chromophores derived from coumarin utilized as fluorescent brighteners, laser colors, and natural nonlinear optical constituents $[32,33]$. Thus, the UVvisible spectra was measured for the newly coumarin derivatives 5a-f as shown in figure 4 and Table 3 . The results showed compounds $\mathbf{5 c}$, 5e and $\mathbf{5 f}$ exhibited strong absorption bands at 366, 358 and $360 \mathrm{~nm}$.

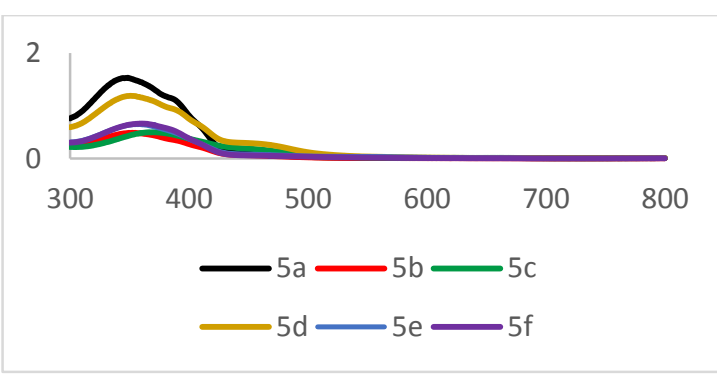

Fig. 4. UV-visible spectra of compounds 5a-f in DMF

In addition, the fluorescence quantum yields of the newly prepared compounds 5a-f were measured in order to see whether they could be used as fluorescent materials in laser devices.

The quantum yield of photo-excited fluorescence (QY) is the ratio of the number of photons emitted and the number of photons absorbed. Rhodamine $6 \mathrm{G}$ used as a standard $\left(\eta_{\text {ref }}=0.94, \mathrm{DMF}\right)$ in this determination 
in DMF, the QY was determined using the following equation below.

$Q Y=Q Y_{\text {ref }} \frac{\eta^{2}}{\eta_{\text {ref }}^{2}} \frac{I}{I_{\text {ref }}} \frac{A_{\text {ref }}}{A}$

QY: The sample which have emission quantum yield.

$\mathrm{QY}_{\text {ref }}$ : Reference`s quantum yield.

$\mathrm{A}_{\text {ref }}$ and A: The absorbance of the reference and sample at the excitation wavelength, respectively.

$\mathrm{I}_{\mathrm{ref}}$ and I: The calculated integrated emission band areas of the reference and sample, respectively.

$\eta_{\text {ref }}$ and $\eta$ : The refractive index of the reference and sample.

This approach is based on the fact that the unknowns of the equation must be the same quantitatively for different fluorescent solutions when compared under equal excitation conditions, such as acquisition of excitation wavelength and aperture settings (slit width).
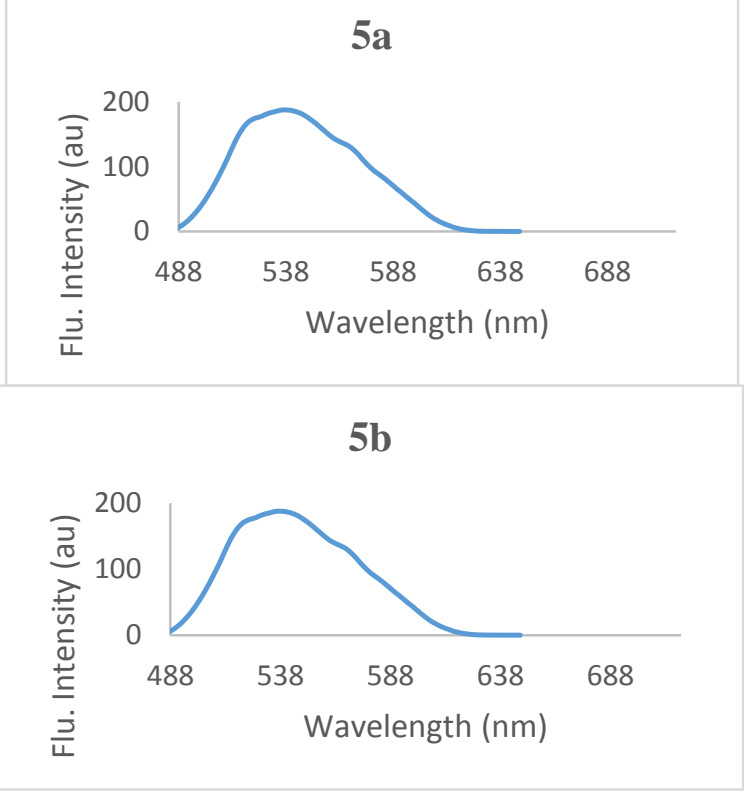
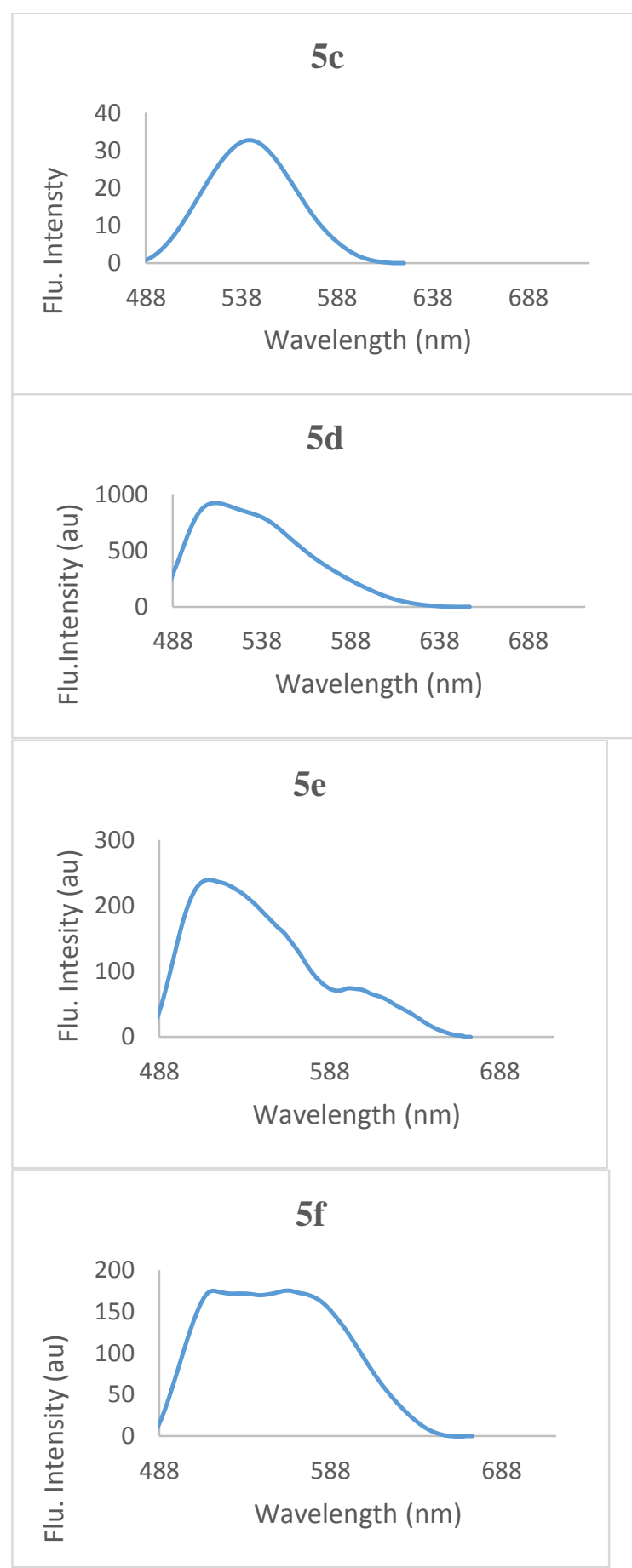

Fig. 5. Florescence spectra of compounds 5a-f in $\mathrm{DMF} ; \lambda_{\max }=488 \mathrm{~nm}$

Table 3. Fluorescent properties of synthesized compounds $\mathbf{5 a - f}$

\begin{tabular}{cccc}
\hline Compound no. & $\boldsymbol{\lambda}_{\max }{ }^{\text {abs }}$ & $\lambda_{\max }$ flu & QY \\
$\mathbf{5 a}$ & 347 & 540 & 0.034 \\
$\mathbf{5 b}$ & 352 & 538 & 0.028 \\
$\mathbf{5 c}$ & 366 & 546 & 0.091 \\
$\mathbf{5 d}$ & 350 & 515 & 0.001 \\
$\mathbf{5 e}$ & 358 & 517 & 0.002 \\
$\mathbf{5 f}$ & 360 & 522 & 0.004 \\
\hline
\end{tabular}

Egypt. J. Chem. 65, No. 2 (2022) 
Fluorescence quantum yields of compounds 5a-c were determined to be $0.034,0.028$ and 0.091 , respectively. The calculated fluorescence quantum yield values are computable with the fluorescent images (resulted from irradiation at $448 \mathrm{~nm}$ ) as shown in figure 5. From this present study it concluded that coumarin derivatives 5a-f showed remarkably moderate quantum yields. Such relatively moderate fluorescence quantum yields of coumarin containing benzothiazole moiety can be used as fluorescent tests in different optoelectronic applications.

\section{Conclusion}

In conclusion, a novel compounds of benzothiazoles contained coumarin moiety 5a-f was synthesized via the reaction of 2cyanomethylbenzthiazole $\mathbf{1}$ with 2-hydroxy-5(aryldiazenyl)benzaldehyde derivatives 2a-f under grindstone method in the presence of sodium hydroxide at room temperature. The structures of all the newly prepared compounds were proved by ${ }^{1} \mathrm{H}$ NMR, IR, MS and elemental analyses. The fluorescence properties of the coumarin derivatives revealed high absorption bands ranging from 347 to $366 \mathrm{~nm}$, which are caused by the $\pi-\pi^{*}$ electronic transition. Fluorescence quantum yields of coumarin derivatives were also found to be in the 0.034-0.091 range. In addition, the antimicrobial activities against Escherichia coli, Klebsiella pneumonia, Pseudomonas aeruginosa, Staphylococcus aureus, Streptococcus mutans and Candida albicans strains have been also screened and some of the examined compounds showed activities against the tested bacterial and fungal strains.

\section{References}

[1] Lkpa, C. B. C., Onoja, S. O., Okwareji, A. O., Synthesis and antibacterial activities of benzothiazole derivatives of sulphonamides, Acta Chemica Malaysia (ACMY) 4, 55 (2020.

[2] Padalkar, V. S., Borse, B. N., Gupta, V. D., Phatangare, K. R., Umap, V. S. P. G., Sekar, N., Synthesis and antimicrobial activity of novel 2substituted benzimidazole, benzoxazole and benzothiazole derivatives, Arabian J. of Chemistry, 9, 1125 (2016).

[3] Ugwu, D. I., Okoro, U. C., Ukoha, P. O., Gupta, A., Okafor, S. N., Novel anti-inflammatory and analgesic agents: synthesis, molecular docking and in vivo studies, J. Enzyme Inhib. Med. Chem. 33, 405 (2018).

[4] Asiri, Y. I., Alsayari, A., Muhsinah, A. B., Mabkhot, Y. N., Hassan, M. Z., Benzothiazole as potential antiviral agents, J. Pharmacy and Pharmacology, 7 (2020).

[5] Irfan, A., Batoo, F., Andleeb, S., Naqvi, Z., Islam, A., Osman, S. M., Nocentini, A., Alissa, S. A.,
Supuran, C. T., Benzothiazole derivatives as anticancer agents, J. Enzyme Inhib Med Chem., 35, 265 (2020).

[6] Evans, W. C., Trease and Evans Pharmacognosy, Elsevier Ltd., ${ }^{16}$ th edition, 2009.

[7] Spino, C., Dodier, M., Sotheeswaran, S., AntiHIV coumarins from calophyllum seed oil, Bioorg. and Med. Chem. Lett., 8, 3475 (1998).

[8] Choi, J., Lee, K. T., Ka, H., Jung, W. T., Jung, H. J., Park, H. J., Constituents of the essential oil of the Cinnamomum cassia stem bark and the biological properties, Archives of Pharmacal Research, 24, 418 (2001).

[9] Alt, S., Mitchenall, L. A., Maxwell, A., Heide, L., Inhibition of DNA gyrase and DNA topoisomerase IV of Staphylococcus aureus and Escherichia coli by aminocoumarin antibiotics, J. Antimicrobial Chemotherapy, 66, 2061 (2011).

[10] Arif, K., Rahman, M. A., A Review of Warfarin dosing and monitoring, Faridpur Med. Coll. J. 13, 40 (2018).

[11] Gebauer, M., Synthesis and structure-activity relationships of novel warfarin derivatives, Bioorg. \& Med. Chem., 15, 2414 (2007).

[12] Mansee,A. H., Chenl, W., Mulchandani, A., Biodetoxification of coumaphos insecticide using immobilized escherichia coli expressing organophosphorus hydrolase enzyme on cell surface, Biotechnol. Bioprocess Eng. 5, 436 (2000).

[13] Azzam, R. A., Osman, R. R., Elgemeie, G. H., Efficient synthesis and docking studies of novel benzothiazole-based pyrimidinesulfonamide scaffolds as new antiviral agents and Hsp90 $\alpha$ inhibitors, Am. Chem. Soc. (Omega), 5, 1640, (2020).

[14] Elgemeie, G. H., Elghandour, A. H., Activated nitriles in heterocyclic synthesis: novel synthesis of 5-imino-5H-[1]benzopyrano[3,4-c]pyridine$4(3 H)$-thiones and their oxo analogues Bull. Chem. Soc. Japan, 63, 1230 (1990).

[15] Elgemeie, G. H., Metwally, N. H., Jones, P. G., 1,2-Dimethylpyrido[1,2-a]benzimidazole-4carbonitrile, Acta Cryst., C54, 1871 (1998).

[16] Elgemeie, G. H., Metwally, N. H., Reactions of sodium salts of 3-(hydroxymethylene)alkan-2ones with enamines: synthesis of polysubstituted pyridines. J. Chem. Research (S), 208 (1999).

[17] Elgemeie, G. H., Metwally, N. H., Novel synthesis of 5-amino-1-arylsulfonyl-4-pyrazolin3-ones as a new class of $\mathrm{N}$-sulfonylated pyrazoles, J. Chem. Research (S), 384, (1999).

[18] Elgemeie, G. H., Metwally, N. H., Synthesis of structurally related purines: Benzimidazo[1,2-a] pyridines, Benzimidazo[1,2-c]pyrimidines, and pyrazolo[1,5-a]pyrimidines. Monatsh. Chem., 131, 779 (2000). 
[19] Elgemeie, G. H., Metwally, N. H., Hopf, H., Jones, P. G., 5-Amino-1-phenylsulfonyl-4pyrazolin-3-one, Acta Cryst., C54, 136 (1988).

[20] Metwally, N. H., Elgemeie, G. H., Jones, P. G., Crystal structure of ethyl 2-(5-amino-1benzenesulfonyl-3-oxo-2,3-dihydro-1H-pyrazol2-yl)acetate, Acta Cryst., E76, 481 (2020).

[21] Azzam, R. A., Elgemeie, G. H., Osman, R. R., Synthesis of novel pyrido[2,1-b]benzothiazole and $N$-substituted 2-pyridylbenzothiazole derivatives showing remarkable fluorescence and biological activities, J. Mol. Structure, 1173, 707 (2020).

[22] Azzam, R. A., Elboshi, H. A., Elgemeie, G. H., Novel synthesis and antiviral evaluation of new benzothiazole-bearing N-sulfonamide 2pyridone derivatives as USP7 enzyme inhibitors, Am. Chem. Soc. (Omega), 5, 30023 (2020).

[23] Metwally, N. H., Mohamed, M. S., Ragab, E. A., Design, synthesis, anticancer evaluation, molecular docking and cell cycle analysis of 3methyl-4,7-dihydropyrazolo [1,5- $a]$ pyrimidine derivatives as potent histone lysine, Bioorg. Chem., 88102928 (2019).

[24] Metwally, N. H., Saad, G. R., Abdelwahab, E. A., Grafting of multiwalled carbon nanotubes with pyrazole derivatives: characterization, antimicrobial activity and molecular docking study, Inter. J. of Nanomedicine, 14, 6645 (2019).

[25] Metwally, N. H., Radwan, I. T., El-Serwy, W. S., Mohamed, M. A., Design, synthesis, DNA assessment and molecular docking study of novel 2-(pyridin-2-ylimino) thiazolidin-4-one derivatives as potent antifungal agents. Bioorg. Chem., 84, 456 (2019).

[26] Metwally, N. H., Mohamed, M. S., New imidazolone derivatives comprising a benzoate or sulfonamide moiety as anti-inflammatory and antibacterial inhibitors: Design, synthesis, selective COX-2, DHFR and molecularmodeling study; Bioorg. Chem., 99, 103438 (2020).

[27] Metwally, N. H., Abdallah, S. O., Mohasen, M. M., Design, green one-pot synthesis and molecular docking study of novel $N, N$ bis(cyanoacetyl) hydrazines and bis-coumarins as effective inhibitors of DNA gyrase and topoisomerase IV. Bioorg. Chem., 97, 103672 (2020).

[28] Metwally, N. H., Ragab, E. A., Mohamed, M. S., Synthesis of some novel N5-sulfonylated and N1-alkylated pyrazole derivatives and their antimicrobial activity in conjunction with molecular docking study, J. Hetero. Chem. 57, 1698 (2020).
[29] Elgemeie, G. H., El- Maksoud, F. A., Nitriles in heterocyclic synthesis: Novel synthesis of pyrido- $[2,1-b]$ benzothiazoles, pyrimido $[6,1-b]$ benzo- thiazoles and pyrazolo[4,3-c]pyrimidine derivatives, Heterocycles, 24, 349 (1986).

[30] Halve, A. K., Bhashkar, B., Sharma, V., Bhadauria, R., Kankoriya, A., Soni, A., Tiwari, $\mathrm{K}$., Synthesis and in vitro antimicrobial studies of some new 3-[phenyldiazenyl]benzaldehyde $N$ phenylthio- semicarbazones, J. Enzyme Inhib. and Med. Chem., 23, 77 (2008).

[31] Fischer, A., Cremer, C., Stelzer, E. H. K., Fluorescence of coumarins and xanthenes after two-photon absorption with a pulsed titaniumsapphire laser, Applied Optics 34,1989 (1995).

[32] Sokolowsk, J., Czajkowski, W., Podsiadly, R., The photostability of some fluorescent disperse dyes derivatives of coumarin, Dyes and Pigments, 49, 187 (2001).

[33] Scott, A. C., Laboratory control of antimicrobial therapy. In: Collee JG et al. eds. Practical Medical Microbiology, 13th Edition. Edinburgh: Churchill Livingstone, 161(1989). 